\title{
MEMÓRIAS DE MARTA DE JULIA LOPES DE ALMEIDA: UMA NARRADORA BURGUESA NUM CONTEXTO DE EXCLUSÃO SOCIAL
}

\author{
MEMORIES OF MARTA DE JULIA LOPES DE ALMEIDA: A BOURGEOIS NARRATOR IN A \\ CONTEXT OF SOCIAL EXCLUSION \\ https://orcid.org/0000-0002-1601-6176 Eurídice Hespanhol Macedo Pessoa ${ }^{A}$ \\ ${ }^{\text {A }}$ Universidade do Estado do Rio de Janeiro (Uerj), São Gonçalo, RJ, Brasil \\ Recebido em: 2 maio 2021 | Aceito em: 29 ag. 2021 \\ Correspondência: Eurídice Hespanhol Macedo Pessoa (ehm.pessoa@ gmail.com)
}

\begin{abstract}
Resumo
O presente artigo tem como principal interesse apresentar o romance Memórias de Marta de Julia Lopes de Almeida, editado como livro pela primeira vez em 1899. Trata-se de um romance narrado por uma mulher em primeira pessoa, ambientado num típico cortiço, moradia popular dos finais do século XIX na cidade do rio de janeiro, Brasil. Junto a leitura, foram feitas análises da construção dos enunciados que deram origem ao romance, com base na análise do discurso em Bakhtin, vasculhando as entrelinhas interpretativas com auxílio do paradigma indiciário de Ginzburg, busca-se encontrar pistas que nos mostrem na perspectiva do protagonismo feminino as questões de gênero, raça, classe e formação educacional. A pesquisa objetiva colaborar para a história das mulheres e seus possíveis desdobramentos.
\end{abstract}

Palavras-chave: protagonismo feminino; interseccionalidade; história das mulheres; formação educacional.

\begin{abstract}
The main interest of this article is to present the novel Memórias de Marta by Julia Lopes de Almeida, published as a book for the first time in 1899. It is a novel narrated by a woman in the first person, set in a typical tenement, popular housing of the late 19th century in the city of Rio de Janeiro, Brazil. Along with the reading, analyzes were made of the construction of the statements that gave rise to the novel, based on the analysis of the discourse in Bakhtin, combing the interpretive lines with the help of Ginzburg's indicative paradigm, we seek to find clues that show us from the perspective of protagonism gender, race, class and educational background for women. The research aims to contribute to the history of women and their possible consequences.
\end{abstract}

Keywords: Female protagonism; Intersectionality; History of women; educational background. 


\title{
Memórias de Marta de Julia Lopes de Almeida: uma narradora burguesa num contexto de exclusão social
}

Foram inúmeras as tentativas bravamente travadas entre iniciar a ler o "Memórias de Marta" e sentir vontade de parar, por entrar em choro convulsivo. Mas ciente da importância desta narrativa, enfrentei a leitura, agora, em plena pandemia da nova corona vírus, a covid 19i em meio às lágrimas, que neste período estão produtivas. Choro os amigos mortos, choro por sentir a desesperança e comparar o número de mulheres em dificuldade neste momento, talvez, experimentando o mesmo sofrimento da mãe de Marta, a viúva que se mudou para um cortiço em finais do século XIX. O sofrimento da pequena órfã de pai, me remeteu a minha família no interior, à minha mãe que ficou viúva com 5 filhos menores e a mim mesma, viúva com três filhos, o mais novo com sete anos. A narrativa nos remonta à situação das mulheres nos finais dos oitocentos. Marta relata sua infância, a maior lembrança é a morte do pai e o medo de Deus:

\begin{abstract}
Na morte, não era o pavor da cova negra o que me assustava mais, era a presença do Pae do Ceu, de que me fallavam a todo o instante, como uma. punição para as minhas travessuras e um prêmio para virtudes que eu não conhecia e me pareciam de assombro! Effectivamente, que ouvia eu desde manhã até á noite? " Menina, não faça assim que Deus castiga". Por isso eu tremia toda, pensando que me queriam levar com meu pae para a presença desse Deus tremendo, inflexivel, tão alto que se não pudesse curvar até as minhas faces lacrimosas, para um beijo de perdão ou de piedade. (ALMEIDA, 1889, p. 7-8).
\end{abstract}

O que impressiona são os detalhes impressos na memória da personagem, o significado do medo, originado da imposição religiosa, invadindo os lares, a alma daquelas crianças, a vida, tudo.

Após a morte do pai, as duas Martas ${ }^{\mathrm{ii}}$,mãe e filha, recomeçam uma vida totalmente diferente, pois são obrigadas a abandonar a casa que viviam. A narrativa tem como cenário uma moradia típica dos finais do século XIX, um cortiço ${ }^{\mathrm{iii}}$.

Memórias de Marta foi o primeiro romance editado pela autora, publicado antes como folhetim no jornal Tribuna Liberal do Rio de Janeiro, de 3 de dezembro de 1888 a 17 de janeiro de 1889, conforme informações do editor em ALMEIDA, 2009, p. 489. Dez anos depois, em 1899 virou livro pela Editora Casa Durski, de Sorocaba (São Paulo), com a terceira edição (segunda em livro), pela Livraria Francesa e Estrangeira Truchy-Leroy, em Paris, provavelmente em 1930. Segundo Rosani Salomoni:

(...) as diferenças constatadas, cabe mencionar as variantes relativas ao conteúdo do início da narrativa, nas três edições, e a omissão de alguns parágrafos finais nas duas edições em livro, o que, quando estudadas 
criticamente, ampliam o universo romanesco e criam novas expectativas de leitura. ((SALOMONI, apud ALÓS, 2005, p.691).

O livro retrata em suas páginas traços literários, precisamente do real-naturalismo. Ambientado em um cortiço no Rio de Janeiro, Capital Imperial do Brasil de então. Podemos dizer que Memórias de Marta por ter sido editado antes de O Cortiço, de Aluízio Azevedo, publicado em 1890, foi o primeiro romance brasileiro a trazer um cortiço como cenário narrativo. Ainda, segundo a pesquisadora Rosane Saint-Denis Salomoni:

(...) no decorrer da leitura encontramos muitos pontos de contato entre as duas obras: Memórias de Marta e O Cortiço, perfeitamente aceitáveis em razão dos dois autores conviverem na mesma época, frequentarem espaços em comum e relacionarem-se amigavelmente, fato comprovado pela correspondência trocada entre os dois artistas. (SALOMONI, apud ALOS, 2005, p. 692).

No romance temos duas Martas, mãe e filha, sendo que a segunda é a narradora personagem. Marta, a protagonista, relata suas memórias, mesclando as passagens de tempo entre passado e presente, o livro todo traz em suas páginas lembranças dolorosas, sentimentos e visões de mundo de uma menina que conviveu desde a infância numa comunidade popular do início do século, narrando a difícil convivência e a miséria exposta dentro do cortiço, sua nova casa após o falecimento do pai:

Não posso acompanhar o movimento de transição da nossa vida, desse tempo para outro, em que habitamos um cortiço de São Cristóvão. Ahi já minha mãe não tinha criados, nem mesmo a velhinha que nos acompanhava outr'ora, e que partiu não sei para onde, nem com quem. Lembro-me de que vivíamos nós duas sós; minha mãe engommando para fora, desde manhã até á noite, sem resignação, arrancando suspiros do peito magro, mostrando continuamente as queimaduras das mãos e a aspereza da pele dos braços estragada pelo sabão. (ALMEIDA, 1899, p. 9).

Analisando o fragmento acima, o fragmento do texto nos mostra uma Marta de origem burguesa, numa casa com criados e uma velhinha que as acompanhava. Trazendo as interpretações semânticas à tona, verifica-se na posição das duas Martas o rebaixamento momentâneo de classe social. Trata-se de uma mulher burguesa com sua filha pequena, sendo obrigada a assumir a posição de arrimo de família num contexto onde a mulher era desamparada em casos de viuvez ou abandono paterno. Poucas mulheres sobreviviam sem sofrimentos naquela realidade excludente em relação ao gênero. No entanto podemos, de certa forma, trazer as questões múltiplas dos sentimentos que a perda do marido poderia trazer naquele contexto carioca de início de século XX. A viuvez, certamente era um grave problema para qualquer mulher naqueles tempos. Levando em conta o estilo de vida, o modelo que cada família poderia 
ou não estar incluída naquela sociedade dirigida por uma ótica patriarcal, vamos encontrar variações que podem considerar desde a situação financeira às limitações de idade, o status social, perpassando, certamente, pelas questões de classe e raça. A mãe da nossa narradora, havia perdido tudo, o marido havia cometido suicídio após ser acusado de um roubo que não cometeu. Tiveram que abandonar a casa onde viviam com conforto, a mudança fez com que Dona Marta encontrasse como atividade ser lavadeira e engomadeira. Esta profissão é comum no Brasil dos oitocentos, especialmente entre as mulheres das classes populares em busca do sustendo da família. Sobre as questões das viúvas em finais dos oitocentos e início do século vinte temos:

\begin{abstract}
As viúvas oitocentistas, identificadas pelo seu luto ostensivo, exibindo sua dor e suas mazelas, eram uma lembrança indesejável da finitude da vida e a expressão do sofrimento, da perda e do vazio. Contidas, silenciosas e silenciadas, passaram ao largo da História e dos assuntos considerados interessantes e que poderiam atrair a atenção do mundo acadêmico, exceto quando o estudo se relacionava à família e ao envelhecimento. (BRANDÃO, 2013, p. 17)
\end{abstract}

Portanto, a vida para as mulheres viúvas que perdiam seus bens materiais, naquele contexto, não apontava caminhos de superação ao abandono e falta de recursos, uma das saídas era lavarem e engomarem roupas como ganho e sustento. A vida no cortiço, reunia essas mulheres em torno de um único local onde havia água para a lavagem das roupas dos clientes. Era realmente uma atividade popular:

\begin{abstract}
Lavar roupas era um negócio no século XIX, não apenas no Brasil; uma profissão que concentrava principalmente mulheres pobres, que trabalhavam em conjunto. As lavadeiras faziam parte da paisagem das cidades, causando brigas e confusões ao redor de bicas, chafarizes e rios. Zola escreveu A Taberna (materiais, naquele), em 1876. $\mathrm{O}$ romance conta a história de Gerais, uma lavadeira que ensaia um projeto de emancipação econômica, mas que, pressionada pelas circunstâncias e pelo alcoolismo, vê sua vida arruinar-se. No Rio de Janeiro, os lugares que reuniam tanta gente acabavam por se tornar locais de confusão, sendo muitas vezes alvo de batidas policiais. Brigas por amor, por tentativas de roubo ou mesmo por espaço ao redor das bicas e fontes de água acabavam inúmeras vezes numa profusão de palavrões. (MONTELEONE, 2019, p. s.n.).
\end{abstract}

Em virtude dessa atividade, a mãe da protagonista precisava sair às ruas para entregar as roupas limpas e engomadas, numa dessas entregas, a narrativa nos apresenta o momento em que Marta enxerga a diferença entre a sua miséria e a vida da filha de uma das clientes de sua mãe:

Como me achei triste e feio o lado d'aquela menina da minha idade! Ella, muito alva, corada, olhos rasgados a brilhantes de alegria e de orgulho, o vestido claro, curto, bibe branco bordado, meias pretas esticadas por cima dos joelhos. Eu, pálida, o cabelo muito liso, feito em uma trança apertada, as pernas magras, as meias de algodão engelhadas, o vestido de lã cor de havana, muito comprido e esgarçado, os sapatos de 
duraque rotos! Ella compreendeu-me e demorou-se maldosamente a confrontar-me com altivez. Eu sentia-me humilhada e com vontade de chorar (ALMEIDA, 1899, p. 17).

Porém, apesar de conviver e viver os mesmos cotidianos das misérias dos seus vizinhos, no decorrer do romance a narradora enfatiza a vida no cortiço com olhares claramente burgueses, trazendo uma realidade escura e triste, nada de belo é apresentado das gentes de sua vizinhança, naquele ambiente apresentado como sujo, fétido e até insalubre, ela manifesta estranheza e repulsa.

Chamavam-me lesma! molle ! palerma! E riam-se das minhas quedas, da minha magreza a da minha timidez. Eu em começo estranhava aquella moradia, com tanta gente, tanto barulho, num corredor tão comprido e infecto onde o ar entrava contrafeito, a água das barrellas se empoçava entre as pedras deseguaes da calçada. (Almeida, 1899, p. 11)

A menina branca de origem burguesa que se tornou uma menina pobre, descobriu na escola o desejo de ser como sua professora, seu esforço a levou a ser escolhida como discípula e protegida da sua professora branca e bem casada, o que foi primordial para o futuro da nossa narradora personagem.

Os estereótipos aparecem o tempo todo nos sentimentos de rejeição de Marta ante a situação da sua vida no cortiço. Até as manifestações de afeto eram envoltas de sofrimento e imagens que singravam a leitura pela forma dura nas transcrições da narradora:

$\mathrm{Eu}$, às vezes, ia brincar para a porta com umas crianças da vizinhança: mas as pequenas eram brutinhas e magoavam-me os pulsos, puxando com força por mim. Eu cahia, chorava alto, minha mãe corria a soccorrer-me e levava-me ao collo para dentro. Sentia-lhe a respiração offegante, as mãos muito quentes e os beiços seccos, queimados, que ella unia ás minhas faces em beijos longos e sentidos. (ALMEIDA, 1899, p. 10).

Nesse romance, não encontraremos nada que nos possa remeter a uma situação folhetinesca. Na página 12, Marta narra sua timidez e docilidade, o que pode ser traduzido por medo e passividade diante do que chamava de vida bruta das outras crianças, seu almoço quase sempre era café ralo com um pedaço de pão, apesar dos sacrifícios maternos, descrito de forma pesarosa pela filha ao ver com imenso sofrimento a vida da mãe.

Não menos difícil é uma cena na casa de uma personagem a quem o livro se refere como "Ilhoa"iv , Marta fica na casa desta vizinha quando a mãe precisa sair para entregar as roupas engomadas. A filha da portuguesa, vendo que ela está com fome, tira dos guardados um pedaço de carne com farinha. Ao flagrar a menina comendo, a "ilhoa" avança na filha que ofereceu a iguaria com demonstrações de violência. 
A Carolina, filha mais velha da ilhoa, era compassiva e bondosa. Ha flores nos pântanos, e reflectem-se muitas vezes na lama os raios das estrellas. Eu gostava d'ella, que era como que uma aza a proteger-me das maldades dos irmãos mais novos. Nesse dia ella notou que eu tinha fome: è que já aviam passado quatro horas sobre o meu pobre almoço de café fraco e pão secco. Eu tinha apenas sete annos a nessa edade o appetjte não dorme; pois bem, a Carolina, condoída, deu-me um boccado de carne com farinha, dizendo-me ao mesmo tampo umas cousas consoladoras a meigas. Eu devorava verdadeiramente aquelle acepipe raro quando a ilhôa chegou. Vendo-me, perguntou admirada: - Quem te deu isso? (..) Eu tinha a bocca cheia a não pude responder logo. A Carolina disse sem titubear, com toda a sua costumada serenidade, que tinha sido ella A mãe enfureceu-se e fechando apertadamente as mães, deu-lhe, com toda a rijeza de seus pulsos de ferro, uma meia dúzia de soccos que a deitaram por terra. A Carolina affirmava que o quinhão que me dera era o seu, só o seu, que ella não tinha vontade de jantar. (...) - Não me importa, continuava a enraivecida mulher, bato-te para que saibas que não se mexe na comida sem minha licença! (ALMEIDA, 1899, p. 13/14)

Estranha-se a maneira da narradora se referir a filha da Ilhoa, Carolina, dizendo que há flores no pântano. Percebe-se na personagem narradora uma constante e repetida ideia de mostrar os moradores do cortiço como sujos, fétidos, brutos, violentos com raríssimas exceções. Marca a possibilidade de que na classe burguesa ${ }^{\mathrm{v}}$, considerando que Marta é oriunda das classes burguesas, sim, porque no início do romance, ela se recorda dos criados que sua mãe tinha, da profissão do pai, que viaja como caixeiro viajante ${ }^{\text {vi }}$, uma atividade comercial, o que nos remete a essa origem. Nas entrelinhas desses enunciados construídos para dar voz a protagonista, parece haver um grau comparativo que eleva a classe de sua origem a uma classe superior, pois nada, nem ninguém naquele cortiço livrava-se das críticas contundentes da nossa narradora implacável e desiludida com a sorte.

A questão de classe é apresentada com maior força ainda, numa cena que mostra a diferença entre a filha de uma cliente para quem a mãe de Marta lavava roupa e a Marta menina, que rememora esse passado, expondo seu sentimento de criança diante da enorme desigualdade, sentindo-se um trapo, revoltada sem saber o porquê, mas sentindo o imenso vazio que a separava da filha dessa cliente:

No vão de uma janella, ao lado da moringueira envernizada, uma menina da minha edade vestia, em uma boneca de cara de louça e corpo de pellica, um traje de velludo bronzeado, prendendo-lhe nos cabellos muito louros um laço da mesma côr. Vendome, sentou-se em um banco baixo e poz-se a tirar de um cofre fatos de seda, de setim e de cachemira para a sua querida boneca. Chamou-me, fez-me sentar a seu lado, mais por vaidade que por outra cousa, e desenrolou á minha vista o grande enxoval de Mlle. Rosa. Ria-se muito das minhas exclamações e movia mademoiselle em uns tregeitos graciosos, dizendo palavras amáveis e pretenciosas. Depois, enfastiada de brincar, fallou-me da mestra, das amigas, de uma festa de Natal a que assistira, de caixas de amêndoas forradas de seda, de bombons, de jóias, de passeios. conduziu-me depois para defronte do espelho, um grande espelho, que vinha do tecto ao chão, tomando uma parede toda. Como me achei triste e feia o lado d'aquella menina da minha edade! (...) Eu sentia-me humilhada a com vontade de chorar (ALMEIDA, 1899, p. 17). 
A construção deste texto em Julia Lopes pode ser uma estrada que atravessa questões de gênero e classe. Seguindo, Marta ganha roupas usadas e dessa forma, pode frequentar a escola:

Lucinda não estava, fora para //o collegio. A mãe tinha separado umas roupas, já curtas e apertadas para a filha, e deu-m'as. D'essa vez custou-me menos a receber da caridade. O primeiro passo é sempre o mais difficil em uma vereda desconhecida. Habitua-se a gente a tudo até ao perigo, até á humilhação! Perguntaram-me se eu já sabia ler. Minha mãe respondeu que não. — Mas porque a não mette na escola?! Ella já tem edade de aprender... - E que eu não podia mandar minha filha tão pobresinha para. a escola... agora que tem esta roupa sim, posso trazel-a asseiadinha e leval-a lá. - Faz bem, faz bem, disseram ameigando-me, as bondosas senhoras. (AMEIDA, 1899, p. 19).

A esmola, as "doações" caridosas que muito foram incentivadas por parte da igreja para que as mulheres das classes burgueses pudessem se apresentar à vida pública como senhoras bondosas, também é narrada no livro História das mulheres no Brasil:

(...) os religiosos reforçavam a hierarquia existente entre homens e mulheres e o ideal de reclusão feminina. Entretanto, ao mesmo tempo promovia um modelo de sacrifício pessoal e resignação a ser adotado pelas mulheres, a instituição religiosa podia fornecer-lhes um espaço de atuação (...) A própria instituição reservava alguns papéis ativos para elas ao incentivar que praticassem filantropia. (HABNER, 2016, p.48)

No mesmo texto, vamos da caridade à perversidade, práticas urbanas sentidas na pena de Julia Lopes: Maneco, o filho da portuguesa, com menos de 10 anos sofre de alcoolismo, vítima do dono do botequim que lhe dava bebida para vê-lo embriagado e fazer chacota do mesmo. A descrição primeira sobre o menino, é como muitas outras, mostrando as impressões tristes de Marta:

O Manéco tinha oito annos, era magro, orelhudo e pallido; cheirava sempre a cachaça e Vivia fumando as pontas de cigarros encontradas no chão. Era elle quem mais me affligia, entretanto quem mais me procurava! Quando se ria mostrava as gengivas arroxadas, como se estivessem cozidas pelo álcool, e os dentes grandes, deseguaes, ainda muito novos. Era alto para a edade, mas magrissimo, com o peito fundo, e braços e as pernas moles. (ALMEIDA, 1899, p. 21).

A cachaça, bebida brasileira, atualmente conhecida no mundo todo, tinha a fama de ser a bebida dos desgraçados, dos pobres, das classes populares. Tal é a fama da mesma, que quando se pensava em álcoolismo, a imagem social era do pobre, do homem sem posses, caído na sarjeta das ruas, sujo, sem moral ou caráter para livrar-se do vício. Ao ser pertencente às classes populares, era atribuído culpa por sua "desgeneração". Cabe aqui, um parêntese sobre a ideia social do alcoolatra naquele momento e sobre a bebida "cachaça":

Cabe ressaltar, no entanto, que a cachaça mesmo sendo apreciada por pessoas de diferentes segmentos sociais, geralmente, esteve associada às camadas mais humildes da população, adquirindo também seu consumo certo preconceito (bebida de pobre, 
de negro, sendo, inclusive, menos valorizada em relação a outros tipos de bebidas), conforme Alencastro esse aspecto está correlacionado ao seu papel de mercadoriaescambo de escravos africanos e também pela associação que se estabeleceu entre a cachaça brasileira e São Benedito, o santo negro, esta "representação racial do santo se agregou ao uso de bebida que até o início do século XX foi considerada no Brasil como uma bebida quase exclusivamente de negros”.( Sales, p. 172/173)

Da morte de Manéco. os recortes de desigualdades continuam através da fala da nossa protagonista enredo afora. A primeira amiga de Marta na escola, é descrita como tantos outros personagens mestiços das tramas de Julia Lopes como a "mulata" e os costumeiros estereótipos de raça (feia, escura, marcada de bexigas, pouco inteligente...), que flanavam nos finais do século XIX, sob os preconceitos de raça:

Dediquei-me principalmente a uma menina mulata, que, mais adiantada do que eu, tinha a paciência de ensinar-me as lições. Ficava a meu lado; era feia, escura, marcada de bexigas, com olhos pequeninos e amortecidos, o cabello muito encaracolado a curto. Chamava-se Mathilde, teria doze anos e estava havia três na escola; era pouco intelligente, e não passava do Segundo livro de leitura, por mais esforços que a professora fizesse. (ALMEIDA, 1899, p.24)

Sobre Matilde, a narrativa relata um roubo que foi descoberto em flagrante, as humilhações na correção do mesmo faz de Matilde uma aluna proscrita na classe. Com o tempo, o romance nos relata que a "mulata" ficou violenta, revoltada e acabou sendo expulsa. Nesta passagem do texto, vamos pedir a presença de Lélia Gonzalez:

(...) discriminação de sexo e raça faz das mulheres negras o segmento mais explorado e oprimido da sociedade brasileira., limitando suas possibilidades de ascensão. Em termos de educação, por exemplo, é importante enfatizar que uma visão depreciativa dos negros é transmitida nos textos escolares e perpetuada em uma estética racista (...). (GONZALEZ, 2020, p. 160).

Passando essa observação de Gonzalez para o advento dos ideais médicos recém chegados ao Brasil em finais do século XIX, Lélia também nos elucida:

(...) sabemos que o colonialismo Europeu, nos termos com que hoje o definimos, configura-se no decorrer da segunda metade do século XIX. Nesse mesmo período o racismo se constitui como a "ciência" da superioridade euro cristã (branca e patriarcal), na medida em que se estruturava o modelo ariano de explicação que viria a ser não só o referencial das classificações triádicas do evolucionismo positivista das nascentes ciências do homem, como ainda hoje direciona o olhar da produção acadêmica ocidental. (GONZALEZ, 2020, p. 129.)

Na fala de Lélia Gonzalez temos o nascimento da eugenia ${ }^{\text {vii }}$ que neste contexto já começa a influenciar os pensamentos sociais no Brasil, acentuando a situação de discriminação e exclusão das populações negras após escravizados, limitando os direitos em relação à educação e ascensão social.

Movendo o leitor por esse mar de desigualdades, percebe-se nas entrelinhas do discurso, uma possível intencionalidade no sentido de rasgar o véu que socialmente deu aos mais 
abastados a ideia que corresponde à meritocracia, aos privilégios de classe. Podemos constatar no romance, a questão da interseccionalidade presente, ou seja, Júlia Lopes de Almeida evidencia em seu romance como a questão relativa à classe social interfere na maneira como as mulheres são vistas, tratadas e reconhecidas. Segundo Davis (2016) a opressão que a mulher negra sofre não é igual à da mulher branca, além da questão do gênero, está interseccionalizada também com as discriminações de raça e de classe. A mulher branca passa discriminações relativas ao gênero, por causa da cultura patriarcal, mas não sofre com as discriminações de raça, lembrando que estes também estão relacionados aos componentes de classe, pois a maior parte da população que pertencente as classes populares são negras - por motivos segregacionistas históricos.

Mesmo presenciando tantos episódios excludentes, a escola foi para nossa narradora o lugar mais feliz, a imagem da esperança, o espaço de futuro para subir socialmente. Seu sonho sempre presente: ser professora, tirar a mãe do cortiço e dar a ela uma vida mais digna, sem tantos sacrifícios. Num contexto repleto de marcas de Interseccionalidade ${ }^{\text {viii }}$, de desigualdades sociais, retratado pela narradora em Memórias de Marta, as tristezas são expostas, a melancolia das férias que a privavam da escola, que para ela era o momento de livrar-se do seu ambiente domiciliar, enclausuravam-na no quarto do cortiço, infeliz até ficar doente. O romance é uma ode à educação, como se a escola fosse, para as meninas das classes populares o único e maior caminho para um futuro sem as misérias narradas por Marta. Tornar-se professora é desejo da personagem. Já naquele momento, as mulheres haviam conquistado o magistério nas classes iniciais. Podemos dizer que foi uma conquista, apesar de encontrarmos na história da educação a alusão ao pendor maternal para exercer as funções de educar nas séries iniciais. Naquele momento, falava-se na necessidade de educar o sexo feminino, oferecendo para as mulheres o papel de educadoras da infância.

Desta forma, foi atribuído à mulher uma espécie de dom natural para o exercício do magistério infantil. Portanto, houve um deslocamento do lar para as salas de aula, como se este, também fosse um local santo, uma atividade missionária. Essa possível introdução do sexo feminino no espaço educacional, relativizou uma nova questão de gênero e pode relativamente ter impedido a inserção de muitas meninas em outros campos profissionais.

No percurso da história da profissão docente, encontra-se o ingresso da mulher professora repercutindo significativamente no processo de definições e construção da identidade do magistério, o que, segundo Nunes e Ramalho (2006), trouxe modificações acerca da identidade de gênero e da identidade profissional da docência. $\mathrm{Na}$ construção da identidade de gênero estão presentes as relações entre espaço público e privado, bem como as representações do que era julgado "adequado" ao feminino e ao masculino. No caso do magistério primário, essas relações se encontram 
imbricadas na construção da identidade docente e no processo de transformação desta profissão como feminina. No entanto, os autores alertam ser necessário compreender este processo de feminização sem desconsiderar que a saída dos homens da sala de aula não "significou sua ausência do campo educacional, no qual permaneceram e permanecem em cargos de comando e poder, o que denota uma significativa presença da dominação masculina no âmbito da docência” (UEKANE, 2010, p.44)

Marta progredia na escola a custa de muito esforço para a realização do seu sonho, amparada pela lida penosa da mãe, queimando os braços no ferro de engomar, que de tão pesado foi apelidado popularmente de maxambomba ${ }^{\mathrm{ix}}$. Uma nova estudante ganhou sua admiração, seu nome era Clara Silvestre, que também parece evadir da escola, com quem mais tarde Marta tem um encontro inesperado e surpreendente. No reencontro das duas colegas de classe, Clara lhe declara grande admiração e diz que gostaria de ter sido igual a ela, no texto, a situação é descrita num diálogo semi velado, mas que nas entrelinhas, a moça vestida com exagero e um certo requinte, está na companhia de diversos rapazes estranhos que recamam em voz alta sua volta à presença deles dentro de um automóvel, o que nos dá a entender que a menina vaidosa e sonhadora, tornara-se uma prostituta. Sobre os cotidianos escolares apresentados por Marta, a filha da D. Marta, a lavadeira, na de meninas, ela fala de evasão escolar, apresentando o fato com pouco ou nada relevante:

Em cada anno que começa ha uma onda nova de meninas, que entram, e um grande vácuo de meninas que sahiram, algumas sem uma palavra ao menos de despedida! Cada dia occorre-nos à lembrança uma ou outra collega que não tornámos a vêr! (ALMEIDA, 1899, p. 41).

Neste contexto em finais do século XIX, estudo sobre questões de evasão escolar, esclarecem:

A identificação da presença da população de origem africana nas salas de aula não significa negar as tensões na convivência de crianças de origens raciais diferenciadas e os conflitos subsequentes. Como apontado anteriormente, Almeida (1899) comenta que muitos pais tiravam os filhos das escolas pública, temendo a convivência com crianças negras. (GOUVEA, 2007, p.133)

Num momento repleto de marcas de interseccionalidade, de desigualdades sociais, retratado pela narradora em Memórias de Marta, as tristezas são expostas, a melancolia das férias que a privavam da escola, que para ela era o momento de livrar-se do seu ambiente domiciliar, enclausuravam-na no quarto do cortiço, infeliz até ficar doente. O romance é uma ode à educação, como se a escola fosse, para as meninas das classes populares o maior caminho para um futuro sem as misérias narradas por Marta. Trata-se de um imenso estímulo à educação formal para as meninas, discutida naquele final de século. Tornar-se professora é desejo da personagem, como se fosse a única saída para alguém que se enxergava tão feia, sem atrativos, 
sem nada que pudesse chamar a atenção de um rapaz, já que o casamento para as mulheres naquele período, era considerado o caminho ideal. No entanto, Marta tornou-se discípula de sua Mestra, que a orientou, ajudando e valorizando seu esforço até tornar-se professora. Na prática, a educação naquele momento, poderia lançar mão da formação pela prática, como nos relata Gondra e Schueler (2008):

À primeira vista, ao analisarmos os saberes prescritos para a formação escolar das meninas, podemos salientar, como o fez grande parte da historiografia especializada na temática da escolarização, que a preparação para vida doméstica era o ideal de instrução primária feminina, pelo menos conforme foi estabelecido pela legislação. Estes estudos afirmam que, durante todo o século XIX, tal diferenciação curricular se relacionou à manutenção de um modelo dominante e hierárquico nas relações sociais de gênero, que implicavam o domínio patriarcal e a reserva de funções domésticas às mulheres (...). Além disso, é preciso considerar também que um dos modelos de aprendizagem do ofício docente então vigente implicava o recrutamento de aprendizes, alunos e alunas das próprias escolas que, na condição de monitores(as), auxiliares e professores(as) adjuntos(as), eram formados(as) pela prática, por meio de processos de transmissão direta dos saberes do ofício. Nesse sentido, ao longo do século, grande parte das meninas e mulheres que se fizeram professoras primárias, aderindo ao magistério em escolas e colégios públicos ou particulares (...). (GONDRA e SCHUELER, 2008, P. 205/206)

Em relação à educação formal, para muitas meninas das classes populares, este era um tema que nem sequer era cogitado, suas presenças e importância na manutenção da vida, substituindo a mãe que precisava exercer atividades de ganho, ou mesmo andando pelas ruas da cidade em busca de diversas atividades em meio a pobreza que se instalou após a abolição da escravatura, tornava-as vítimas do distanciamento com as letras e as escolas. Elas muito cedo assumiam o papel de ajudante da mãe, como era o caso de Carolina, filha da portuguesa. Trabalhava e abandonava-se no cuidado com os irmãos e assumia pela imposição austera da mãe, o fazer doméstico para manutenção da família:

Passava as tardes em casa da vizinha, brincando com a Rita e o Manéco, enquanto a Carolina trabalhava. A pobre soffria calada as rebentinas da mãe, estava sempre magra, espigada, e no seu rosto oval e sardento, os olhos claros derramavam uma tristeza impressionadora. Era a doença, era o cansaço, porque ella estupidificada pelo meio, nem tinha consciência do sofrimento". (ALMEIDA, 1899, p.30).

Segundo Schueler (1999):

Em meio a essa população que dominava as ruas, as crianças e jovens representavam seus papéis de "pequenos agentes" na luta cotidiana. Moleques de recados, vendedores ambulantes, criados e aprendizes, as crianças populares, escravas, livres nacionais ou estrangeiras, exerceram diversas funções na sociedade e teceram com suas mãos um quinhão da história. Nas principais cidades do Império, as crianças e jovens representavam espetáculos à parte. As fontes primárias disponíveis, como os Relatórios Provinciais, os arquivos de polícia, os relatos dos viajantes e contemporâneos, os documentos das instituições de assistência leiga, religiosa e educacional, assim como outros inúmeros documentos, chamam a atenção para a presença e a vivência marcantes das crianças e jovens na vida do Império, 
notadamente àquelas pertencentes às classes trabalhadoras e pobres. (SCHUELER, 1999, p. 1)

Não seria difícil encontrar razões para que tantas crianças fossem assíduas frequentadoras das ruas, o romance mostra os cortiços com seus cômodos apertados e a condição de higiene comprometida, vem nos dizer para além das lembranças de Marta, as mazelas de todos os tempos, nos remetendo ao momento de pandemia neste 2021, com o coronavírus. Como estarão nossos alunos das escolas públicas, das nossas periferias, onde um pequeno cômodo pode abrigar mais de uma família? Quantas enfermidades ainda sem recurso... e a vida parca. Nos conta Marta, sobre as doenças que certamente acometiam outras crianças:

Ao expirar das férias, cahi gravemente doente. Desenvolvera-se no cortiço a epidemia terrível de diphteria, e o sarampo. Minha mãe, enlouquecida, não me desamparava... velava assídua noite e dia, por sua pobre doentinha, evitando o menor golpe de ar, proporcionando todo possível conforto. Logo no primeiro dia de doença, correu á casa do médico, de manhã, mas só á noite é que elle appareceu, o que a desesperava de impaciência... eu gemia baixo, enfraquecida e prostrada pela intensidade da febre. Delirei, tive suffocações medonhas e só depois de duas semanas pude levantar-me, muito tremula a muito impertinente. (ALMEIDA, 1899, p.37).

Em diversos momentos da história, podemos encontrar preocupações relacionadas às condições de saúde dos centros urbanos. As questões vindas do continente Europeu, as dificuldades e os projetos que sempre permaneciam na intenção de banir para a capital uma imagem da pobreza. Os cortiços, considerados habitações coletivas, eram alvo desses projetos:

Políticas de controle e limpeza das habitações coletivas e dos espaços "imundos" das cidades foram alvos das batalhas dos poderes públicos, os quais recorriam aos ideais de racionalidade científica, "ordem" e "progresso" para justificarem sua intervenção, a despeito das diferenças sociais e das lutas de classes. Apontando para a necessidade de higienizar e sanear, vacinar, construir diques e lavadouros, habitações salubres, edifícios, escolas e colégios etc., os higienistas, médicos e demais dirigentes imperiais intentavam não apenas transformar e modernizar as cidades, mas atingir os costumes e hábitos da população. (SCHUELER, 1999, p. 1)

Encontramos em Júlia Lopes a imagem triste narrada em primeira pessoa pela personagem Marta, os crimes que aconteciam no cortiço, o meio embrutecido em partes da narrativa e por fim, a volta à escola, onde Marta estava imensamente feliz por poder levar Lucia, uma das filhas da Portuguesa. Até que, num certo dia, na volta da escola, encontram ajuntamento e barulho em frente ao botequim e a polícia segurando a "Ilhoa" possessa de raiva, depois de ter partido com violência para cima do dono do botequim que embriagava o Maneco, 
agora, desenganado por um médico, em estado avançado de cirrose. A tristeza deste momento, a fragilidade da vida pobre. Carolina, cuidou do irmão até o último suspiro:

(...), entretanto, a Carolina lavava o irmão com um panno molhado, e vestia-o com muito cuidado, como se temesse desprender-lhe os braços ou as pernas.... Pesava um abatimento extraordinário sobre aquela gente. Nenhum grito, nenhum accesso, nenhum ataque perturbou a tristeza grave, a solemnidade d'aquella morte tão esperada e tão triste.... Estavam todos cansados, silenciosos e quietos. Chegou emfim a hora das despedidas. A Rita beijou o irmão na testa, fechando os olhos, com um leve estremecimento que lhe percorreu o corpo. A Carolina beijou-o na boca, innundandoo de lagrimas. 0 pae abençoou-o muito commovido; a mãe então suspendeu nos braços aquelle corpo imóvel de uma magreza transparente, e conchegou-o ao peito, como se o quizesse guardar; depois beijou-o longamente, longamente, e foi depol-o no caixão, sem flores, sem um crucifixo, sem nada. (ALMEIDA, 1899, p.)

A morte de Maneco passa pela trama como um feixe de realidade naquele espaço pobre e sem cores. A dor da família é igual a dor de qualquer menino que morre, mas as circunstâncias, o motivo torpe, o desamparo daquela miséria, realmente oferece um rastro de denúncia que perpassa a questão de classe, raça e gênero. Fosse Maneco uma menina, não seria oferecido a ele os goles diários de cachaça para tolo divertimento.

O conceito de maternagem ${ }^{\mathrm{x}}$, é emoldurado na despedida da portuguesa do seu filho de 10 anos e na dedicação e amores incondicionais da D. Marta, a mãe, e implícito na voz da narradora do romance em questão, lançando para a mulher um certo grau de culpabilidade por eventuais "erros" na educação da prole:

Com que orgulho eu penso na desvelada sollicitude que tem em geral a mulher brasileira para o filho amado! Não o repudia nunca, trabalha ou morre por elle. Coração cheio de amor, perdoemos-lhe os erros da educação que lhe transmitte e abençoemol-a pelo que ama e pelo que padece! (ALMEIDA, 1899, p. 140)

A maternidade na figura da mãe de Marta, retrata a extensão da maternagem na santificação da mulher segundo os padrões positivistas ${ }^{\mathrm{xi}}$ daquele final de século: uma proposta para que as mulheres tivessem o lar como seu altar: Assim, a função básica da mulher é manter a harmonia na sociedade doméstica, educar
os filhos dentro da mentalidade da ordem, da sujeição e do respeito aos pais e, por
extensão, aos adultos e às autoridades constituídas. O lugar de sua atuação se restringe
às paredes domésticas, onde ela se mantém como 'rainha do lar', na dependência
econômica de seus maridos que, segundo Augusto Comte "deve sustentar a mulher, a
fim de que ela possa preencher convenientemente seu santo destino social".
(PEREIRA, 2016, p. 237)

Mesmo que esse modelo de mulher e essa santidade atribuída ao sexo feminino fosse algo considerado importante, as classes populares forneciam mão de obra para as fábricas e industrias. Mulheres e crianças foram mão de obra tão necessária, que segundo Scott (2016, p. 18): Em 1872 (ano do primeiro recenseamento geral do Brasil), as mulheres constituíam $76 \%$ 
da força de trabalho nas fábricas. Portanto, como podemos notar, as mulheres das classes populares sempre trabalharam para o sustento de suas famílias, de maneira formal ou informal, mas sempre foram à luta por dinheiro e às ruas para cumprir suas labutas diárias, e a narrativa expressa esses movimentos cotidianos nas habitações do cortiço onde residiam nossas protagonistas.

O progresso de Marta na escola e seu afinco para tornar-se mestra foram aos poucos ganhando forma:

Ao fim de dois annos fiz exame com desembaraço e firmeza: ficaram ahtonitas as professoras, que me sabiam tímida e nervosa. Foi um dia de triumpho para mim, que nunca me vira tão bonita, com o cabello crespo a papelotes, o vestido branco transparente a fita azul do uniforme a tiracollo. Aquelle vestido, aquelia fita, quantas horas de trabalho custaram á minha pobre mãe! Hoje vejoos atravez das lagrimas de saudade e reconhecimento; então via-os entre os risos da vaidade e da ignorância, a ignorância natural na despreoccupação da meninice! (ALMEIDA, 1899, p.280.)

Com o pequeno salário da ajudante da professora, as duas Martas mudaram-se para a casinha perto da escola. Enfim fora do cortiço, o lugar que Marta tanto rejeitou a vida toda, de onde sempre quis sair, de onde presenciou tantas desgraças, o cômodo sombrio e frio ficava para trás. Não era nenhum palacete, uma casinha simples, mas onde entrava o sol. Talvez isso fosse o que todo ser desse mundo deveria ter direito: ao sol.

Fizemos a mudança. Agora entrava sem frouxidão a luz do dia na nossa morada alegre, com um bello cheiro a nova, toda envernizada e limpa. A mobília destacava-se de velha, rara e feia naquelle ninho risonho e fresco; mas.... ora! isso a pouco e pouco se iria arranjando também. Minha mãe trabalhava sempre; assim era preciso para sustentar-nos. A nossa vida não decorria num scenario tão lugubre, mas estava longe de poder ser considerada feliz. (ALMEIDA, 1899, p. 77).

A vida de menina Marta, figura como exemplo de perseverança e honestidade, modelo da sociedade de então, num discurso de pureza incontestável. Parece que o texto quer nos dizer o tempo todo que sua origem burguesa, branca, não a havia feito para o ambiente do cortiço, que sua tenacidade e objetivo serviria para todas as moças que lessem suas memórias:

Assim cheguei á edade de vinte annos, passando o melhor tempo da vida a estudar para ensinar, ou curvada sobre a costura, ao lado de minha mãe, que enfraquecia muito e trabalhava sempre.... Eu não tinha amigas intimas, nem amores; não dançava nunca, não lia novelas... (ALMEIDA, 1899, p. 82).

O entanto, para tornar-se professora, ela e seu empenho, conquistaram a ajuda e a atenção da sua Mestra, que a conduziu desde pequena para realizar o se derradeiro sonho, o que nos leva a crer nas dificuldades das mulheres das classes populares para atingir qualquer posto educacional de maior categoria social. As dificuldades pelas quais ela e a mãe passaram, são na 
realidade a certeza maior de que as chances de transformação que tocavam as questões de gênero, classe e raça, precisavam de algo além do incomensurável esforço empreendido por Marta:

A mestra era bondosa, mas impunha-se ao respeito e evitava intimidades. Cumpria rigorosamente os seus deveres e não perdoava a quem não fizesse o mesmo. Ensinarame desde o A B C e tinha por isso grande império sobre mim. Empenhara-se na minha carreira; fallara aos examinadores a meu respeito; protegia-me, levando-me á tarde á Escola. (ALMEIDA, 1899, p.83).

Já na casa nova, apesar da simplicidade, Marta está finalmente feliz, porém começa a sentir-se mal, humor em desalinho e muitas dores de cabeça, tonteiras. A mãe preocupada, leva a filha ao médico e o diagnóstico muito comum à época era histeria:

Ao mesmo tempo vieram-me vertigens e horas de humor execrável, em que eu me fechava em um silencio agressivo e doentio. $\mathrm{O}$ medico aconselhou que me casasse. Aquillo era hysterismo. Taes palavras foram como que chicotadas que me batessem nas faces. Minha mãe ficou-se a olhar para elle, com os seus olhos tristes.... O medico sorriu e remediou: - Ou então uma viagenzinha, distracções... ar puro.... (ALMEIDA, 1899, p. 96).

Mesmo no século XXI, o desejo sexual das mulheres, de certa forma, ainda é invisibilizado e no século XIX era tratado como doença, foi nesse momento que inventaram o vibrador como instrumento de cura. Mais de cem anos de história, as questões de gênero, vinculadas ao desejo ainda são considerados tabu. O vibrador foi inventado como auxiliar no tratamento dos sintomas de uma doença conhecida como "histeria". Não se reconhecia o orgasmo feminino, levou tempo para que a psiquiatria abafasse o caso e o vibrador ocupasse espaço na vida comum das mulheres.

Ilustrando o diagnóstico de Marta, trouxemos um anúncio de uma das páginas da revista Fon Fon de 1907, "reclame" de um remédio que curava os males do útero, afirmando que se o útero estava mal, todo o resto ficaria mal:

Revista FON!FON! 1907 


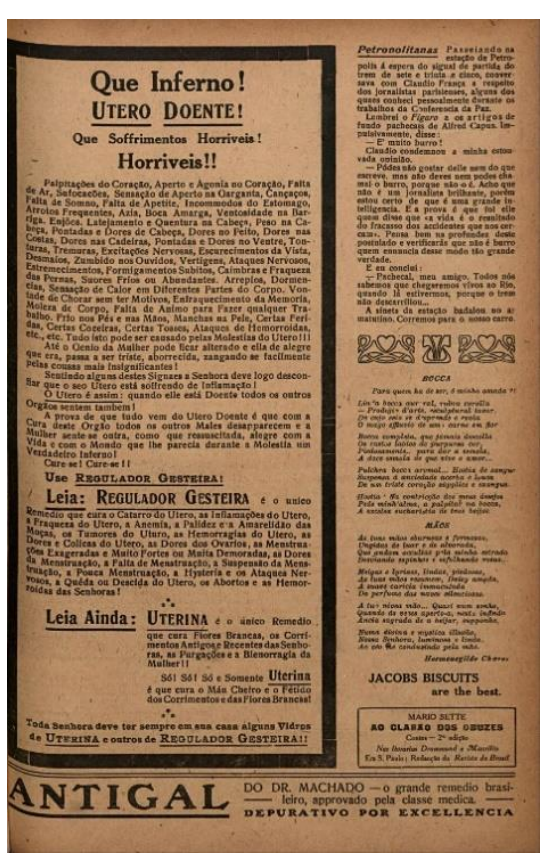

Fonte: Hemeroteca da Bilbioteca Nacional

Atendendo as recomendações do médico e com a ajuda da professora de Marta, Dona Marta consegue que sua filha faça uma viagem de férias para um passeio no interior. Lá, ela conhece um rapaz, primo da sua mestra e se encanta por ele, não passou de mera ilusão e no dia de voltar, encontra-o com uma Americana a dizerem-se: I Love You! Muito clichê, mas talvez fosse o que a época pedisse.

Marta retorna, saudosa de sua inseparável mãe. Enquanto Marta passava um mês de férias longe da Dona Marta, esta mostrava sua carta para um senhor, seu freguês antigo. Este, acaba sendo o pretendente a marido que a mãe tanto sonhava para sua filha: um "homem bom". O casamento acontece em meio a tristeza de Marta e alegria de sua mãe, que a convence com algumas máximas sobre as condições de gênero naquela sociedade: “A reputação da mulher é essencialmente melindrosa. Como o Crystal puro, o mínimo sopro o enturva...." (ALMEIDA,1899, p. 145). Poucos dias depois do casamento acontece a morte da mãe de Marta. O desespero e a imensa tristeza de Marta, agora consoladas pelo esposo, revela um final trágico, onde a nossa Marta, perde seu amor mais precioso, o amor de sua inseparável mãe.

Tive ataques violentos, toda a tarde, rasgando o vestido, mordendo-me, batendo com a cabeça na cabeceira da cama e nas paredes, cerrando os dentes a todos os remédios e alimentos, num desespero atrocíssimo! As Ave-Marias levantei-me e fui postarme ao lado da minha adorada morta; não me arredei d'alli, de joelhos entre o leito e a janella aberta por onde entrava a viração perfumada da noite semeada de estrelas. (ALMEIDA, 1899, p. 162).

\section{Algumas considerações:}


Diante das obras de Julia Lopes, nada parece repetir ou ser de fácil compreensão e análise. Em Memórias de Martas, um texto aparentemente simples, inocente, com flagrantes de cotidiano escolar, abriu-se um leque inesperado para trazer questões de gênero, raça, classe, formação educacional e conceitos cristalizados e reproduzidos naquele início de século, afetando espaços sociais de diversos matizes. Os amplos olhares da narradora personagem traçando caminhos entre presente, passado e sonhos de futuro, revelaram entre a ficção e sua ostensiva verossimilhança a prova de que a arte ao imitar a vida pode invadir o universo do leitor e muito mais do que isso, pode prestar serviços às pesquisas históricas que contribuem para uma visão social de determinado espaço e época. Na voz da protagonista Marta, a menina fraca, medrosa e a professora apaixonada, há muitos conceitos e identidades a serem questionados na busca de pistas, indícios e sinais. Nestas buscas, podemos tentar entender como as mulheres das classes populares dos finais dos oitocentos e início do século XX, são exemplos de coragem e tonaram-se sujeitos de uma força descomunal e de uma perseverança inacreditável para defenderam a vida em meio às adversidades, construindo suas histórias dignas de registro.

\section{Referências}

ALMEIDA, Cláudio Lopes de. D. Julia, abril/2018. [arquivo pessoal]. Rio de Janeiro, 2018.CD-ROM.

ALMEIDA, Julia Lopes de. A falência. São Paulo: Pinguim e Companhia das letras, 2019.

. A Dramaturgia inédita de Júlia Lopes de Almeida. Disponível em:

$<$ http://www.brasa.org/wordpress/Documents/BRASA XI/Michele-Fanini.pdf - >. Acesso em: 3 maio 2018.

. A viúva Simões. [Domínio Público]. (s.d). Em:

. Era uma vez. Rio de Janeiro: J. Ribeiro dos Santos, 1917. Disponível em:

<https://digital.bbm.usp.br/bitstream/bbm/983/1/45000008117_Output.o.pdf>.

. Memórias de Marta. São Paulo: Editora Casa Durski, de Sorocaba. 1899.

. O Livro das donas e donzelas. Rio de Janeiro: Vermelho marinho, 2019.

O livro das noivas. Rio de Janeiro: Castorino Mendes, 1929.

A falência. São Paulo: Pinguim e Companhia das letras, 2019.

ALÓS, Anselmo Peres, Estudos Feministas, Florianópolis, 16(2): 691-713, maio-agosto/2008.

BAKHTIN, Mikhail. Estética da criação verbal. São Paulo: WMF Martins Fontes- 2010. 
BRANDÃO, Helena H. Nagamine. Introdução à análise do discurso. Campinas, S.P.: Editora da UNICAMP, 2004.

BRANDÃO, Silmária Souza. Linhas partidas: viuvez, gênero e geração em salvador (18501920), Artigo do repositório da Universidade federal de Salvador, 2013. Disponível em: $<$ https://repositorio.ufba.br/ri/bitstream/ri/18539/1/Tese\%20-

20Silmaria\%20Souza\%20Brand\%C3\%A3o.pdf>. Acesso em: 29 abr. 2021.

CUNHA, Helena P. Mulher no Espelho. Santa Catarina: Mulheres, 2013

DAVIS, Angela. Mulheres, raça e classe. São Paulo: Boitempo, 2016.

DE LUCA, Leonora. Amazonas do pensamento: a gênese de uma intelectualidade feminina no Brasil. Campinas, 2004. Tese de doutorado. Unicamp/IFCH.

DEL PRIORI, Mary. História das mulheres no Brasil. São Paulo: Contexto, 1997

FANINI, Michele A. Júlia Lopes de Almeida: entre o salão literário e a antessala da Academia Brasileira de Letras (pp.317-338). Revista Estudos de Sociologia. Araraquara, 2009. Disponível em: 〈https://periodicos.fclar.unesp.br/estudos/article/view/1941〉. Acesso em: 26 jun. 2020.

FARIA FILHO, Luciano M.; LOPES, Elaine M.T.; VEIGA, Cynthia G. 500 anos de Educação no Brasil. Belo Horizonte: Autêntica, 2003.

FERREIRA, Ivanir. Escritora mais publicada da Primeira República foi vetada na ABL. Disponível em: <https://jornal.usp.br/ciencias/ciencias-humanas/escritora-mais-publicada-daprimeira-republica-foi-vetada-na-abl/>. Acesso em: 3 maio 2018.

FREITAS, Marcos C., BICCAS, Maurilene de S. História social da educação no Brasil: (1926-1996). São Paulo: Cortez, 2009.

GINZBURG, Carlo. A Micro-história e outros ensaios. Lisboa: Difel, 1989.

GONDRA, José Gonçalves e SCHUELER, Alessandra. Educação, poder e sociedade no império brasileiro. São Paulo: Cortêz, 2008.

GONZALES - Por um feminismo Afro Latino Americano. Org: RIOS, Flavia, LIMA, Márcia. São Paulo: Zahar, 2020.

GOUVEA, Maria Cristina Soares de A escolarização da criança brasileira no século XIX: apontamentos para uma re-escrita. Natal: Revista educação em questão. V28, n14, p. 121/126- 2007. Disponível em: </// C:/Users/Euridice/Downloads/4467Texto\%20do\%20artigo-10500-1-10-20131026.pdf $>$.

GRANGEIA, Fabiana de Araújo Guerra. Oscar Guanabarino e a crítica de arte periódica no Brasil. 2005. Disponível em: <https://www.unicamp.br/chaa/rhaa/atas/atas-IEHA-v1-215222-fabiana\%20de\%20araujo\%20guerra\%20grangeia.pdf>. Acesso em: 24 jun. 2020. 
HABNER, June E. Honra e distinção das famílias. In Nova história das mulheres no Brasil. Org: PINSKY, Carla Bassanezy e PEDRO, Jana Maria. São Paulo: Contexto, 2016.

HABNER, June E. Mulheres da Elite: honra e distinção das famílias. (pp 43-64) In: PINSK, Carla B.; PEDRO, Joana M. Nova história das mulheres no Brasil. São Paulo: Contexto, 2016.

JOURDAN, Camila Alves; VIRGOLINO, Mariana Figueiredo; SILVA, Talita Nunes. Odisseu e Penélope: exemplos de masculino e feminino a serem seguidos na Grécia Arcaica e Clássica. In: LIMA, Alexandre Carneiro Cerqueira. Imagem, Gênero e Espaço: representações da antiguidade: Niterói: Alternativa, 2014.

LOURO, Guacira Lopes. Gênero, sexualidade e educação: uma perspectiva pósestruturalista. Petrópolis: Vozes, 2018.

MONTELEONE, Joana de Moraes . Costureiras, mucamas, lavadeiras e vendedoras: O trabalho feminino no século XIX e o cuidado com as roupas (Rio de Janeiro, 1850-1920). Rev. Estud. Fem. vol.27 no.1 Florianópolis 2019 Epub Feb 21, 2019.

SALES, Eliana. Aspectos da história do álcool e do alcoolismo no século XIX. Pernambuco: Revista Caderno de História da UFPE, ano VII, no 7, p. 167/203, 2010. Disponível em: < https://periodicos.ufpe.br/revistas/cadernosdehistoriaufpe/article/viewFile/110065/21988 >. Acesso em: 4 set. 2021.

SALOMONI, Rosane Saint-Denis. A escritora/os críticos/a escritura: o lugar de Júlia Lopes de Almeida na ficção brasileira. Porto Alegre: UFRGS, 2005. Disponível em: < https://lume.ufrgs.br/handle/10183/81773 >. Acesso em: 28 out. 2019.

SCHUELER, Alessandra, Crianças e escolas na passagem do Império para a República. São Paulo: Rev. bras. Hist. vol.19 n.37 São Paulo Sept. 1999.

SCOTT, Ana Silva. O caleidoscópio dos arranjos familiares, p. 15/42. Org: PINSK, Carla Basanezi e PEDRO, Joana Maria. Nova História da Mulheres no Brasil, São Paulo, Contexto, 2016.

SEPULVEDA, Denize; SEPULVEDA, José Antônio. Conservadorismo, Gêneros e Sexualidades: temáticas que se entrelaçam nas pesquisas do GESDI e do GEPCEB. In: SEPULVEDA, Denize; AMARO, Ivan. Gêneros, Sexualidades e Educação na Ordem do Dia. Curitiba: CRV, 2018.

SEPULVEDA, José Antônio.; SEPULVEDA, Denize. Conservadorismo e Educação Escolar: um exemplo de exclusão. Niterói: Movimento, 2016. Disponível em:

<http://www.revistamovimento.uff.br/index.php/revistamovimento/article/view/319/318>. Acesso em: 25 maio 2018.

UEKANE, Marina Natsume, Mulheres na sala de aula": um estudo acerca do processo de feminização do magistério primário na corte imperial (1854-1888). Niterói: Revista Gênero, v. 11, n. 1, p. 35-64, Dossiê Vozes, Memòrias e Caminhos Percorridos: no Masculino e no 
Feminino. Em: https://periodicos.uff.br/revistagenero/article/view/30933 - Acesso em

04/09/2021.

\begin{abstract}
${ }^{\text {i }}$ A Covid-19 é uma infecção respiratória aguda causada pelo coronavírus SARS-CoV-2, potencialmente grave, de elevada transmissibilidade e de distribuição global. O SARS-CoV-2 é um beta coronavírus descoberto em amostras de lavado bronco alveolar obtidas de pacientes com pneumonia de causa desconhecida na cidade de Wuhan, província de Hubei, China, em dezembro de 2019. Pertence ao subgênero Sarbecovírus da família Coronaviridae e é o sétimo coronavírus conhecido a infectar seres humanos. Os coronavírus são uma grande família de vírus comuns em muitas espécies diferentes de animais, incluindo o homem, camelos, gado, gatos e morcegos. Raramente os coronavírus de animais podem infectar pessoas e depois se espalhar entre seres humanos como já ocorreu com o MERS-CoV e o SARS-CoV-2. Até o momento, não foi definido o reservatório silvestre do SARSCoV-2. (fonte: Ministério da saúde do Brasil - link: https://www.gov.br/saude/pt-br/coronavirus/o-que-e-ocoronavirus)
\end{abstract}

ii Marta, a narradora, conta sua vida desde a infância, sua mãe do mesmo nome, Marta, torna-se lavadeira e engomadeira após a viuvez. O drama realista, em primeira pessoa, é uma saga de dependências entre mãe e filha, com um processo de maternagem que representa, como modelo, a mulher do início do século.

iii Cortiço é a denominação dada, no Brasil, a uma casa cujos cômodos são alugados, servindo cada um deles como habitação para uma família. As instalações sanitárias são comuns. Geralmente ocupados por famílias de baixa renda, os cortiços são chamados tecnicamente de "habitações coletivas precárias de aluguel".

iv Aquela que é natural ou habitante de um dos arquipélagos portugueses (Madeira ou Açores).

${ }^{v}$ Classe social surgida na Europa, com o desenvolvimento dos burgos medievais e o influxo do comércio na sociedade feudal, e que principia a gozar, com o seu enriquecimento, de crescente liberdade e poder, passando a dominar sociopolítica e economicamente as outras classes, a partir da Revolução Francesa 1789.

${ }^{\text {vi }}$ Representante de vendas, empregado de comércio que viaja por conta de uma firma ou, se por conta própria, encarregado dos negócios de várias casas ou ramos; alabama, cometa.

vii $\mathrm{O}$ conceito de eugenia é atrelado a um discurso de melhoria da espécie humana. Nos Estados Unidos, a teoria foi influente na história e cultura norte-americana a partir do século 19, determinando desde leis antimiscigenação que proibiam casamentos interraciais e estabeleciam esterilização compulsória em mulheres latinas, negras e indígenas. No Brasil, a eugenia foi abraçada por médicos, cientistas, jornalistas e intelectuais da época, que também defendiam uma série de práticas para "melhorar" a nação brasileira. Nos jornais, não era incomum encontrar artigos exaltando a eugenia.

viii Interseccionalidade é um conceito sociológico que estuda as interações nas vidas das minorias, entre diversas estruturas de poder. Então, a Interseccionalidade é a consequência de diferentes formas de dominação ou de discriminação. Ela trata das interseções entre estes diversos fenômenos.

ix Vagão ferroviário com mais de um pavimento.

${ }^{\mathrm{x}} \mathrm{O}$ conceito de maternagem na atualidade coloca a mulher numa posição de dedicação incondicional em relação aos filhos. A sociedade contemporânea com base nos postulados positivistas ainda possui uma visão patriarcal do tipo de "mãe ideal": aquela que dedica integralmente seu tempo para cuidar dos filhos, que abdica de seus anseios individuais em benefício da família heteronormativa.

${ }^{\mathrm{xi}} \mathrm{O}$ Positivismo destina à mulher um papel social de rainha do lar como formadora dos seus filhos e conselheira do seu marido, pela qualidade da sua cultura intelectual e pela sua sensibilidade, a mulher representa o poder moderador doméstico, que modifica, pela afeição, o desempenho do homem. É uma filosofia conservadora que trabalha a distinção dos gêneros e defende o poder hegemônico masculino. 